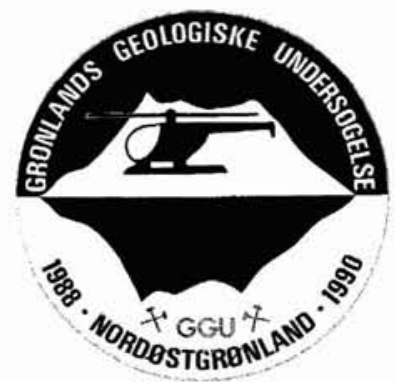

\title{
Sm-Nd model age of an early Proterozoic gabbro-anorthosite from the Caledonian fold belt in North-East Greenland
}

\author{
Ole Stecher and Niels Henriksen
}

\begin{abstract}
Metamorphosed anorthositic and gabbro-anorthositic rocks are found as scattered occurrences in the basement gneisses of the Caledonian fold belt of North-East Greenland. A T $\mathrm{TN}^{\mathrm{PM}}$ model age determined on a gabbro-anorthositic sample yields a value of $2146 \mathrm{Ma}$. This model age is in agreement with the general age of crust formation in the region. The result shows that anorthosites, which are of Archaean derivation in many areas in Greenland, cannot on their own be used as an indicator of Archaean crust.
\end{abstract}

O. S. \& N. H., Geological Survey of Greenland, Øster Voldgade 10, DK-1350 Copenhagen $K$, Denmark.

Occurrences of metamorphosed anorthositic and gabbro-anorthositic rocks are widespread in Greenland in both Archaean and reworked Archaean regions. Their occurrence has been suggested as an indicator of $\mathrm{Ar}$ chaean age (Pulvertaft, 1973), and this relationship has proved correct for many areas in West Greenland (Nunes et al., 1974; Kalsbeek, 1982, 1994; Nutman, 1984; Garde \& Steenfelt, 1989).

In the Caledonian fold belt of North-East Greenland between $74^{\circ}$ and $78^{\circ} \mathrm{N}, \mathrm{Rb}-\mathrm{Sr}$ isotope data and $\mathrm{Sm}-\mathrm{Nd}$ model ages of basement gneisses indicate an early Proterozoic crust formation event around $2000 \mathrm{Ma}$ ago (Kalsbeek et al., 1993). Within this region anorthositic and gabbro-anorthositic rocks occur as: (1) isolated occurrences of foliated and folded rocks on a semi-nunatak about $2 \times 3 \mathrm{~km}$ in size at the rim of the Inland Ice west of Bessel Fjord (c. $76^{\circ} 00^{\prime} \mathrm{N}$; Henriksen et al., 1989), and (2) as layers and lenses in grey gneisses south-west of Dove Bugt (c. $\left.76^{\circ} 30^{\prime} \mathrm{N}\right)$ (Chadwick et al., 1990; Chadwick \& Friend, 1991). Both occurrences typically consist of well foliated rocks, but relict igneous textures are preserved in areas of low deformation. We interpret the anorthositic rocks as originally forming part of a major intrusive complex or complexes.

The presence of these metamorphosed gabbro-anorthositic rocks in the early Proterozoic basement gneiss complex led us to date one of these occurrences in order to test whether the hypothesis of an Archaean derivation was also valid for this part of Greenland. The analysed sample (GGU 327935) was taken from the semi-nunatak west of Bessel Fjord (Fig. 1) which is dominated by anorthositic and gabbro-anorthositic rocks. To the east the gabbro-anorthosite is bordered by a probable fault obscured by Quaternary deposits, which separates the gabbro-anorthosites from a belt of non-migmatised mica schists.

The anorthositic and gabbro-anorthositic rocks display mesoscopic banding conformable with the regional foliation. The rocks have suffered variable degrees of deformation with alternating zones of high and low strain, and appear to be completely recrystallised. Thin sections from several samples indicate the following paragenesis:

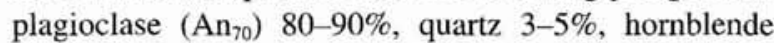
$7-10 \%$, garnet $0-2 \%$, opaque minerals $0-2 \%$. Epidote and chlorite are present as secondary mineral phases.

\section{Analytical data and results}

The gabbro-anorthositic rock was analysed by XRF for major elements, and Sm-Nd concentrations and isotope composition were determined by mass-spectrometry (Table 1).

A mixed ${ }^{147} \mathrm{Sm}^{-150} \mathrm{Nd}$ spike was added to the sample prior to dissolution. The REEs were separated on standard cation exchange resin columns, and Sm and Nd were isolated on capillary quartz columns using $\alpha$-HIBA.

Isotope determinations were performed on a VG 3540 multicollector mass-spectrometer at the Geological Institute, Copenhagen University. The ${ }^{143} \mathrm{Nd} /{ }^{144} \mathrm{Nd}$ ratio is reported relative to a ${ }^{143} \mathrm{Nd} /{ }^{144} \mathrm{Nd}$ value of 0.511118 for 


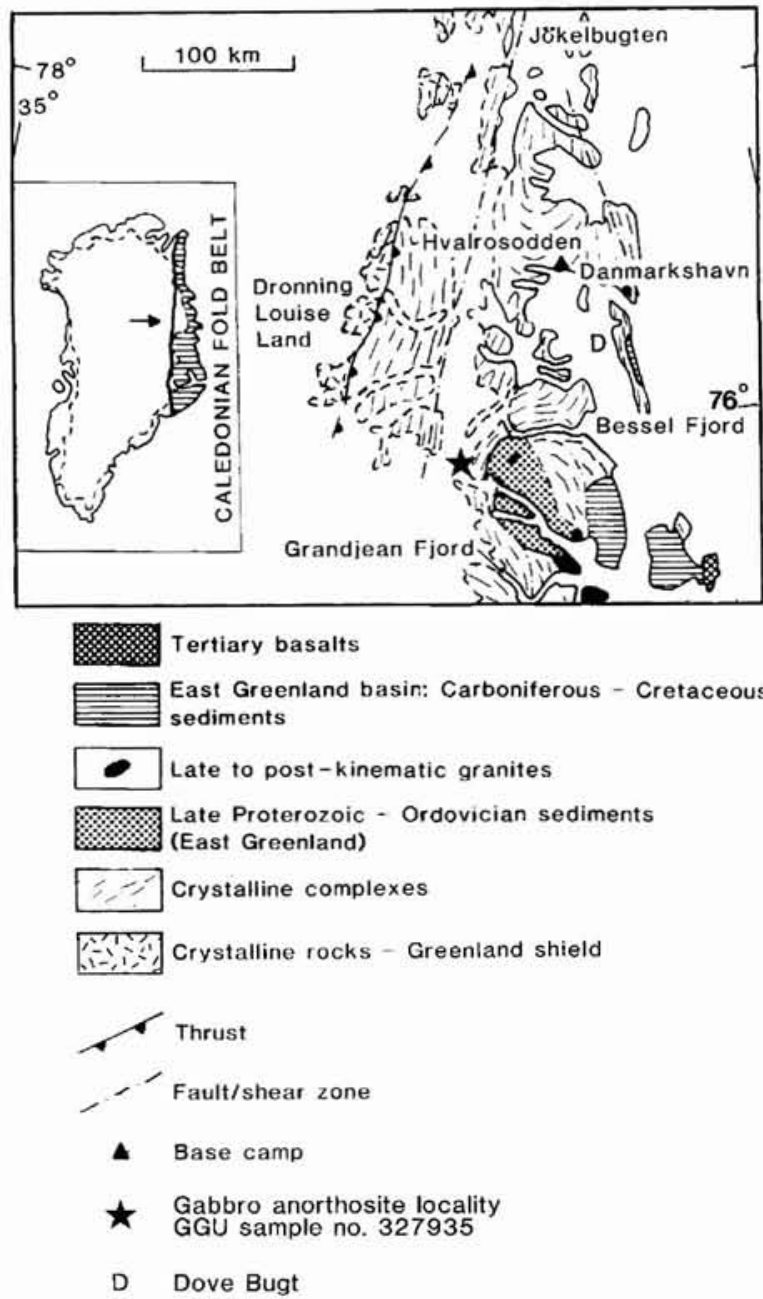

Table 1. Major elements and Sm-Nd data for anorthosite from North-East Greenland

\begin{tabular}{lrlll}
\hline $\mathrm{SiO}_{2}$ & 49.68 & $\mathrm{Sm}$ & $0.2690 \mathrm{ppm}$ \\
$\mathrm{TiO}_{2}$ & 0.19 & $\mathrm{Nd}$ & $1.1347 \mathrm{ppm}$ \\
$\mathrm{Al}_{2} \mathrm{O}_{3}$ & 26.89 & ${ }^{147} \mathrm{Sm} / 144$ & 0.14328 \\
$\mathrm{Fe}_{2} \mathrm{O}_{3}{ }^{\text {TOT }}$ & 4.12 & ${ }^{143} \mathrm{Nd}^{144} \mathrm{Nd}$ & $0.512034 \pm 6(2 s)$ \\
$\mathrm{MnO}$ & 0.06 & $\mathrm{~T}_{\mathrm{Nu}}^{\mathrm{Cu}}$ & $1719 \mathrm{Ma}$ \\
$\mathrm{MgO}$ & 2.88 & $\mathrm{~T}_{\mathrm{Nd}}^{\mathrm{RM}}$ & $2146 \mathrm{Ma}$ \\
$\mathrm{CaO}$ & 13.07 & & \\
$\mathrm{Na}_{2} \mathrm{O}$ & 2.78 & & \\
$\mathrm{~K}_{2} \mathrm{O}$ & 0.08 & & \\
$\mathrm{P}_{2} \mathrm{O}_{5}$ & 0.00 & & \\
vol. & 0.39 & & \\
& 100.14 & & \\
& & & \\
\hline
\end{tabular}

Sample GGU 327935.

Major elements given as wt \% by $\mathrm{XRF}, \mathrm{Fe}_{2} \mathrm{O}_{3}{ }^{\text {TOT }}$ is total iron analysed as $\mathrm{Fe}_{2} \mathrm{O}_{3} ; \mathrm{Sm}$ and $\mathrm{Nd}$ concentrations determined by isotope dilution. $\mathrm{Sm} / \mathrm{Nd}$ is accurate to within $0.2 \%$. the Johnson \& Matthew Nd standard, and has been corrected for fractionation using a ${ }^{146} \mathrm{Nd} /{ }^{144} \mathrm{Nd}$ value of 0.7219 .

The anorthositic parent rock magma is considered to have a mantle origin, and since most mafic and anorthositic Archaean and Proterozoic rocks from Greenland, in common with rocks from other Precambrian complexes, are characterised by slightly positive $\varepsilon_{\mathrm{Nd}}$ values (Stecher et al., 1986), we believe that the $\mathrm{T}_{\mathrm{Nd}}^{\mathrm{RM}}$ model age of DePaolo (1981) gives a better indication of crust extraction age than the $\mathrm{T}_{\mathrm{Nd}}^{\mathrm{CHUR}}$ model age of DePaolo \& Wasserburg (1976) for this rock sample.

The analysed gabbro-anorthositic rock has a $\mathrm{T}_{\mathrm{Nd}}^{\mathrm{PM}}$ model age of $2146 \mathrm{Ma}$, which is significantly lower than that of anorthositic rocks from the Archaean of West Greenland (Ashwal et al., 1989; Stecher et al., 1986), and clearly indicates an early Proterozoic origin for this anorthositic rock.

Model ages calculated from rocks with limited fractionation of $\mathrm{Sm} / \mathrm{Nd}$ relative to their mantle source often prove inaccurate, but the anorthositic sample we have analysed is sufficiently fractionated in $\mathrm{Sm} / \mathrm{Nd}$ relative to its mantle source that more credence can be given to its model age.

\section{Conclusion}

Gabbro-anorthositic and anorthositic rocks from Greenland are well known from Archaean and reworked Archaean areas in West Greenland, and has been suggested as potential indicators for crust of Archaean age. The Sm-Nd model age determination reported here for a sample from basement units within the Caledonian fold belt in North-East Greenland indicates an early Proterozoic (2146 Ma) model age for anorthositic rocks, which is in agreement with the general age of crust formation in the region (Kalsbeek et al., 1993). We therefore conclude that the occurrence of gabbro-anorthositic and anorthositic rocks cannot on its own be used as an indicator of Archaean age crust in this region, and potentially elsewhere.

\section{References}

Ashwal, L. D., Jacobsen, S. B., Myers, J. S., Kalsbeek, F. \& Goldstein, S. J. 1989: Sm-Nd age of the Fiskenaesset Anorthosite Complex, West Greenland. Earth Planet. Sci. Lett. 91, 261-270.

Chadwick, B. \& Friend C. R. L. 1991: The high-grade gneisses in the south-west of Dove Bugt: an old gneiss complex in a deep part of the Caledonides of North-East Greenland. Rapp. Gronlands geol. Unders. 152, 103-111.

Chadwick, B., Friend, C. R. L. \& Higgins A. K. 1990: The 
crystalline rocks of western and southern Dove Bugt, NorthEast Greenland. Rapp. Gronlands geol. Unders. 148, $127-$ 132.

DePaolo, D. J. 1981: Neodymium isotopes in the Colorado Front Range and crust-mantle evolution in the Proterozoic. Nature, Lond. 291, 193-196.

DePaolo, D. J. \& Wasserburg, G. J. 1976: Nd isotopic variations and petrogenetic models. Geophys. Res. Lett. 3, 249-252.

Garde, A. A. \& Steenfelt, A. 1989: A new anorthosite/gabbro complex at Nûgssuaq, central West Greenland. Rapp. Gronlands geol. Unders. 145, 16-20.

Henriksen, N., Friderichsen, J. D., Strachan, R. A., Soper, N. J. \& Higgins, A. K. 1989: Caledonian an pre-Caledonian Geology of the region between Grandjean Fjord and Bessel Fjord $\left(75^{\circ}-76^{\circ} \mathrm{N}\right)$, North-East Greenland. Rapp. Grolands geol. Unders. 145, 90-97.

Kalsbeek, F. 1982: The evolution of the Precambrian shield of Greenland. Geol. Rdsch 71, 38-60.

Kalsbeek, F. 1994: Archaean and early Proterozoic basement provinces in Greenland. Rapp. Gronlands geol. Unders. 160, 37-40.

Kalsbeek, F., Nutman, A. P. \& Taylor P. N. 1993: Palaeoproterozoic basement province in the Caledonian fold belt of NorthEast Greenland. Precambrian Res. 63, 163-178.

Nunes, P. D., Steiger, R. H. \& Bridgwater, D. 1974: A zircon age from gabbro-anorthosite inclusions in the gneisses of the Angmagssalik area, South-East Greenland. Rapp. Gronlands geol. Unders. 66, 21-31.

Nutman, A. P. 1984: Precambrian gneisses and intrusive anorthosite of Smithson Bjerge, Thule district, North-West Greenland. Rapp. Gronlands geol. Unders. 119, 1-31.

Pulvertaft, T. C. R. 1973: Recumbent folding and flat-lying structure in the Precambrian of northern West Greenland. Phil. Trans. R. Soc. Lond. A 273, 535-545.

Stecher O., Carlson R. W., Shirey S. B., Bridgwater D. \& Nielsen, T. [F. D.] 1986: Nd-isotope evidence for the evolution of metavolcanic rocks from the Archaean block of Greenland and Labrador. Terra Cognita 6(2), 236 only. 